\title{
HIGH CONCENTRATIONS OF RADON AND CARBON DIOXIDE IN ENERGY-EFFICIENT FAMILY HOUSES WITHOUT HEAT RECOVERY VENTILATION
}

\author{
Gábor GÉCZI ${ }^{*}$, József BENÉCS ${ }^{1}$, Krisztina KRISTÓF², Márk HORVÁTH³ \\ ${ }^{1}$ Department of Environmental and Building Engineering, Institute of Environmental Systems, Faculty of \\ Mechanical Engineering, Szent István University, Páter K. u. 1, H-2103 Gödöllö, Hungary \\ ${ }^{2}$ Isotope Laboratory, Safety Management and Technical Directorate, Szent István University, \\ Páter K. u. 1, H-2103 Gödöllö, Hungary \\ ${ }^{3}$ Regional Knowledge Center, Szent István University, Páter K. u. 1, H-2103 Gödöllö, Hungary
}

Received 25 October 2016; accepted 22 June 2017

\begin{abstract}
The most significant factors of indoor air quality - besides temperature and humidity - are the concentrations of carbon-dioxide $\left(\mathrm{CO}_{2}\right)$ and radon $\left({ }^{222} \mathrm{Rn}\right)$. Radon seepage is caused by and affected by the materials used in walls and floors, the quality of insulation, cracks and even the amount of pipes running through the walls. The amount of $\mathrm{CO}_{2}$ is predominantly affected by the biological processes of the inhabitants, and possibly by potentially faulty HVAC systems. The energy efficiency related upgrades to family homes, which often only extend to window replacements and better insulation have a significant effect and could potentially increase concentrations of both radon and $\mathrm{CO}_{2}$ which has a significant effect on the well-being of the inhabitants. Our tests conducted in Hungary have proven that by using automated heat recovery ventilation (HRV) both energy efficient operation and low concentrations of radon and $\mathrm{CO}_{2}$ are achievable. Our results prove the significance and prevalence of the issue of higher concentrations of these pollutants, and offer a viable solution.
\end{abstract}

Keywords: indoor air quality, radon, carbon dioxide, energy-efficient building, heat recovery, ventilation.

\section{Introduction}

In the process of designing, building or modernization/ refurbishing of houses, one of the most significant factors besides size and location is the efficiency of the building. This increasing push for efficiency has further highlighted the "comfort theory" which encompasses the all the aspects of indoor air quality. Indoor air quality has been mainly defined by the fluctuation of temperature and humidity, however additional significant aspects include $\mathrm{CO}_{2}$ concentration and the rise and fall of concentrations of other pollutants such as $\mathrm{CO}, \mathrm{SO}_{2}$, radon or formaldehyde (Baumann 2009; Bánhidi, Kajtár 2000).

Comfort Theory highlights that perceived indoor air quality is affected by a multitude of aspects, while people only consciously concentrate on temperature control. Another significant aspect of air quality is humidity. Controlling humidity has become significantly easier in recent years, with the spread of digital humidifiers. Relative humidity and temperature thus can be controlled at a low perceived cost. Some air quality attributes are known superficially, with $\mathrm{CO}_{2}$ and indoor pollutants. For societies with high spread of open flame boilers/heat units and indoor fireplaces, the fear of $\mathrm{CO}$ is the most prevalent. Unfortunately the concentrations of formaldehyde or radon are mostly measured only through scientific research, society en masse is blind to the significance or effects (Frontczak, Wargocki 2011; Goyal et al. 2012). Regrettably, even less research is ongoing or available on cause and effect connections between efficiency factors and indoor air quality parameters.

Two Comfort Theory parameters of indoor air quality should be analyzed further. The first would be $\mathrm{CO}_{2}$, a colorless and in low concentrations odorless gas, a naturally found in the atmosphere. Through breathing, caused by biological processes, the exhaled gas contains around $4 \% \mathrm{CO}_{2}$. Burning fossil fuels leads to significantly higher waste products, one of which is $\mathrm{CO}_{2}$. Being one of the greenhouse gases, $\mathrm{CO}_{2}$ is partially responsible for our planet being habitable, through the temperature control

*Corresponding author. E-mail: geczi.gabor@gek.szie.hu 
effects of the atmosphere. $\mathrm{CO}_{2}$ is heavier than other components of the atmosphere, and thus has the potential to pool and cause breathing difficulties or suffocation through forcing out oxygen. It is nontoxic by itself, even has restorative capacity when absorbed through the skin, by increasing blood flow. This attribute is used by carbon baths or mofettas (Géczi, Béres 2011).

$\mathrm{CO}_{2}$ concentration was first described as an indicator of indoor quality by Max von Pettenkofer. His study published in 1858 described the compositional differences between outdoor and indoor air. Outdoor air $\mathrm{CO}_{2}$ concentration was measured between $300-400 \mathrm{ppm}$, in stark contrast to indoor air reaching nearly $900 \mathrm{ppm}$. He introduced the upper limit of $1000 \mathrm{ppm}$ of $\mathrm{CO}_{2}$ on indoor air quality, which is still used today as the criteria, and referenced as Pettenkofer’s level (Szállási 2001; Kajtár, Szekeres 2011).

As such, the greatest effect of $\mathrm{CO}_{2}$ in terms of air quality is the ability to lower the concentration of oxygen in an air filled chamber. In certain circumstances, it is possible to lower oxygen concentration by simply introducing $\mathrm{CO}_{2}$ due to the difference in mass. The above referenced Petterkofer's level describes acceptable quality levels, humans are able to withstand significantly higher concentrations of $\mathrm{CO}_{2}$. The effects are usually noticeable above $30,000 \mathrm{ppm}$, with the onset of migraine, vomiting, etc. (Géczi, Béres 2011; Kalmár 2016).

The other noteworthy attribute of indoor air quality is radon. Radon is a naturally occurring radioactive inert gas, colorless and odorless and undetectable by humans. Inhalation of various daughter nuclides is a form of radioactive material exposure. The occurrence of radon in indoor air is a result of seepage from brick, slag. Ground level rooms where no basement or cellar is present, radon could potentially occur through infiltration through holes and pipes from soil, further intensified by the pressure difference created by heating or wind. Radon is heavier than air, and has the tendency to occur in increased concentration on the lowest levels of buildings, with significantly lower concentrations on higher levels. Indoor radon concentration can be lowered by ventilation. This is important as during the radioactive decay of radon, alfa radiation emitting daughter nuclide are created, which attach to naturally occurring dust or cigarette smoke. When this dust and smoke is inhaled, upon reaching the lungs, creates constant alfa particle bombardment of the lung tissue, thereby increasing the risk of cancer (Abumurad 2001; Butkus et al. 2005; ICRP 1991, 1993; Katona et al. 2007; Köteles 2007; Lázár et al. 2005; Szabó et al. 2014a, 2014b; Szerbin et al. 1994; Tóth 1992; Tóth et al. 1998; Tóth, Hámori 2005; UNSCEAR 2000).

There are numerous studies on the root cause analysis of the various types of cancer leading the statistics on cause of death. Darby et al. (2005) in research funded by the European Commission claim that radon found in indoor air is responsible for around 20,000 lung cancer deaths in the European Union, a staggering 9\% of all lung cancer cases, and $2 \%$ of all cancer related deaths. In contrast to this, Becker (2003) claims possible medicinal use of radon. Clinical trials have proved that for patients experiencing rheumatism, some degree of improvement was noted by high concentration radon therapy.

There are multiple studies available on measured radon levels of Hungarian homes. A study on 998 homes by István Nikl averaged 128 $\pm 2.7 \mathrm{~Bq} / \mathrm{m}^{3}$ (Nikl 1996). Findings by Somlai et al. (2006) averaged significantly higher readings at $483 \mathrm{~Bq} / \mathrm{m}^{3}$, however the readings were taken in homes in Kövágószöllös in the proximity of the only uranium mine in Hungary that was closed in 1997. Their research centered on showing the effects of the proximity of the mining tunnels on radon concentrations in family homes. Hámori et al. (2006a, 2006b) have performed 15,000 measurements averaging $133 \mathrm{~Bq} / \mathrm{m}^{3}$, with Minda et al. (2009) extending their sampling to a further 17,244 homes. Szabó et al. (2014c) have performed a complex study of internal air quality of 53 homes through recording the effects of building materials used, ambient air temperature, ventilation and precipitation. There is a complex radon map available for Hungary, showing the average radon concentration at $110-150 \mathrm{~Bq} / \mathrm{m}^{3}$ in contrast to the WHO recommended $100 \mathrm{~Bq} / \mathrm{m}^{3}$ (Zeeb, Shannoun 2009).

EU directives limit the indoor radon exposure at a yearly average of $300 \mathrm{~Bq} / \mathrm{m}^{3}$. Hungarian law mandates that a national action plan is to be created and put in place to mitigate the health effects of concentrations of radon and daughter nuclide for residential buildings, if these concentrations reach a yearly average level of $300 \mathrm{~Bq} / \mathrm{m}^{3}$ (Decree 487/2015). Based on the above, numerous groups have started research on the effects of indoor air quality, specifically the occurrence and effects of radon (Hussein et al. 2013; Nikolopoulos 2014b; Müllerová et al. 2016; Vasilyev, Yarmosheenko 2016).

The push for efficient buildings has been developing for some time. Directive 2002/91/EC has prompted Hungarian legislation to develop decree of TNM 7/2006. (V.24.) "Determination of energy characteristics of buildings" and 176/2008. (VI.30.) "Certification of energy characteristics of buildings" on mandating certain efficiency aspects of new construction, as well as establishing nationwide metric of energy efficiency for homes. In direct continuation of this EU directives 2010/31/EU and 2012/27/EU lead to the update of the above mentioned decrees both in terms of allowed materials and stricter thresholds. The industry vocabulary has been updated with the following term: nearly zero energy building. As currently the EU estimates that $40 \%$ of all energy usage, with $36 \%$ of greenhouse gas emissions stemming from buildings. The EU objectives dictate that all new buildings from 2021 are to be nearly zero energy buildings (Magyar, Németh 2015). 2016 January has seen updated energy efficiency metrics from decree 261/2015. (IX.14.). These updated metrics aim to reduce operational costs, increase energy efficiency, especially in the Hungarian housing market, where most of the currently existing homes are classified under outdated, average, or significantly inefficient. 
The efficiency of buildings from the aspects of efficiency of energy usage related to heating/cooling can be improved using the following: reduction of transmission heat loss; reduction of in/exfiltration stemming from design/ construction errors; increasing the efficiency of employed heating/cooling equipment; decreasing the energy loss of employed heating/cooling equipment; and developing internal solutions which lowering net energy need (including: solar gain and increase of internal redistribution of existing heat).

This leads us directly to loss of heating energy through ventilation. Ventilation of rooms/spaces during heating season leads to a loss of room temperature air (used) and a gain of outside (fresh) air, albeit at a much lower temperature, heating of which requires energy. The most energy-efficient solution would be to use the heat energy and enthalpy of the lost and spent room temperature air to partially warm the influx of fresh air. This is solved by the introduction of heat recovery ventilation. The initial low efficiency of $55-60 \%$ has been far eclipsed by the modern variations of these solutions, being able to achieve 92-94\%. Usage of these solutions eliminates the need for window based ventilation, lowering the total energy need of buildings, clearly leading to greater energy efficiency in terms of operation.

Translating this to housing built per the currently applicable regulation in terms of energy efficiency, air to air recuperation of enthalpy could be a significant 15-25\% factor in terms of total energy need (Ebel et al. 2003; Feist et al. 2005; Liu et al. 2010; Schnieders 2009; Benécs, Barótfi 2015). More researches confirm that the use of heat recovery ventilation systems in public-, educational institutions. There are evidences for air quality improvement in parallel with energy consumption reductions and environmental advantages (Kajtár, Szekeres, 2011; Wang et al. 2014a, 2014b).

Data shows that an average sized family home (detached house), with 4 persons present will generate a ventilation heat loss of 2500-3000 kWh/a. This same household has a hot water requirement of $3500-4000 \mathrm{kWh} / \mathrm{a}$, with heating requirement of 6000-9000 kWh/a. Energy efficient buildings can reduce the heating energy requirement to $3000-4000 \mathrm{kWh} / \mathrm{a}$, and passive houses can achieve 1500-2000 kWh/a. Energy efficient buildings generate $35-40 \%$ of their heat requirement due to ventilation, of which $75-92 \%$ can be recovered with the use of air to air heat recovery ventilation.

The drastic reduction in heating energy requirement propelled by the spread of near zero energy buildings is only sustainable if heat recovery ventilation is installed. This would increase efficiency by $40-50 \%$, if the operational patterns of the habitants remain unchanged. To gain further background on the subject, the operators' habits have to be analyzed, as they do pertain to the overall energy efficiency and air quality of the habitat before and after an upgrade in heating and ventilation systems. During colder months previous to the upgrade, air quality was adequate, including low $\mathrm{CO}_{2}$ and low radon readings with barely any ventilation performed.

The key to this lies in the poor insulation qualities of the doors and windows often found on buildings. Through these minute gaps, natural in- and exfiltration happens, without the knowledge or will of the habitants. During upgrades, new doors and windows are fitted, with significantly more accurate seams, air cells and better insulating qualities. The use of these eliminates heat loss through exfiltration and infiltration, however the operators' habits are not changed. This leads to a deterioration of indoor air quality, thereby significantly increasing the need for heat recovery ventilation (Benécs, Barótfi 2015).

A significant aspect of the above mentioned technology is public perception. Energy efficiency through modern technology is perceived as an expensive and long term investment, which society does not value highly. When the allocated budget does not cover a fully equipped energy efficient building, the buyer will move to include items with high perceived value such as windows, exterior insulation and discard or put off items with lower perceived value such as heat recovery ventilation or modern gas boilers.

Our research focuses on measuring the effects of energy efficiency upgrades, such as extra insulation or window and door upgrades in terms of indoor air quality, specifically focusing on the concentrations of radon and $\mathrm{CO}_{2}$. There is no doubt that the reduction of energy use is important for the environmental protection. However, the deterioration of the indoor air quality is detrimental for human health. Some publications in the last period also point out this duality. Kačerauskas (2016) states that the development of technologies is essential element of environmental solutions. Xu et al. (2016) proves the connection between the air quality and the built environment based on questionnaire surveys in China's industrial areas. Dagiliūte and Juozapaitienè (2015) assert that cooperation of engineers, environmental science specialists and social science professionals to achieve effective results in all areas, including environmental protection. The examples presented in this paper reveal that there is a favorable energy usage and environmentally aware solution in building energy which has positive effects for human health also.

\section{Material and methods}

Continuous measurement of indoor air quality focusing on temperature, humidity, radon and $\mathrm{CO}_{2}$ concentration was performed in 10 locations in Budapest, Budaörs and Gödöllö. The instruments were mainly placed in living rooms, with further measurements in cellars and bedrooms. The locations were chosen based on certain attributes, to enable comparative analysis. The chosen buildings are each single level family homes, with no garage or sub-basement underneath the areas of measurement. The buildings differ in methods of construction, materials used in the structure, insulation and doors/windows. There are also differences in overall dimensions of the 
houses, heating systems (boilers, condensation boilers and solar panel), methods of heat transfer (radiator or floor heating) and ventilation systems. Other important parameters affecting the measurements include age composition of habitants with significant differences in habits and preferences with regards to operation of the homes. Based on the abovementioned criteria, our sample of 10 homes is not representative, nevertheless it enables us to pose theories and draw conclusions.

Figure 1 shows a map overlay of the chosen homes, each home represented by a capital letter. Six of these homes lie in Gödöllő, a small town $30 \mathrm{~km}$ northeast of
Budapest with an overall population of 35,000. Three of the locations are in Budapest, with one additional measurement done in Budaörs, an agglomeration town west of the capital.

Table 1 contains the architectural parameters of the homes, overall dimensions range from 70 to $140 \mathrm{~m}^{2}$, with 5 homes built before 1960 and 5 built less than 15 years ago. Half of the homes have had upgrades done in the past, specifically targeting energy efficiency. 3 out of the 10 homes were tested for air permeability, as this is a significant factor of overall energy use, in addition to the previously mentioned structural and size related parameters. For

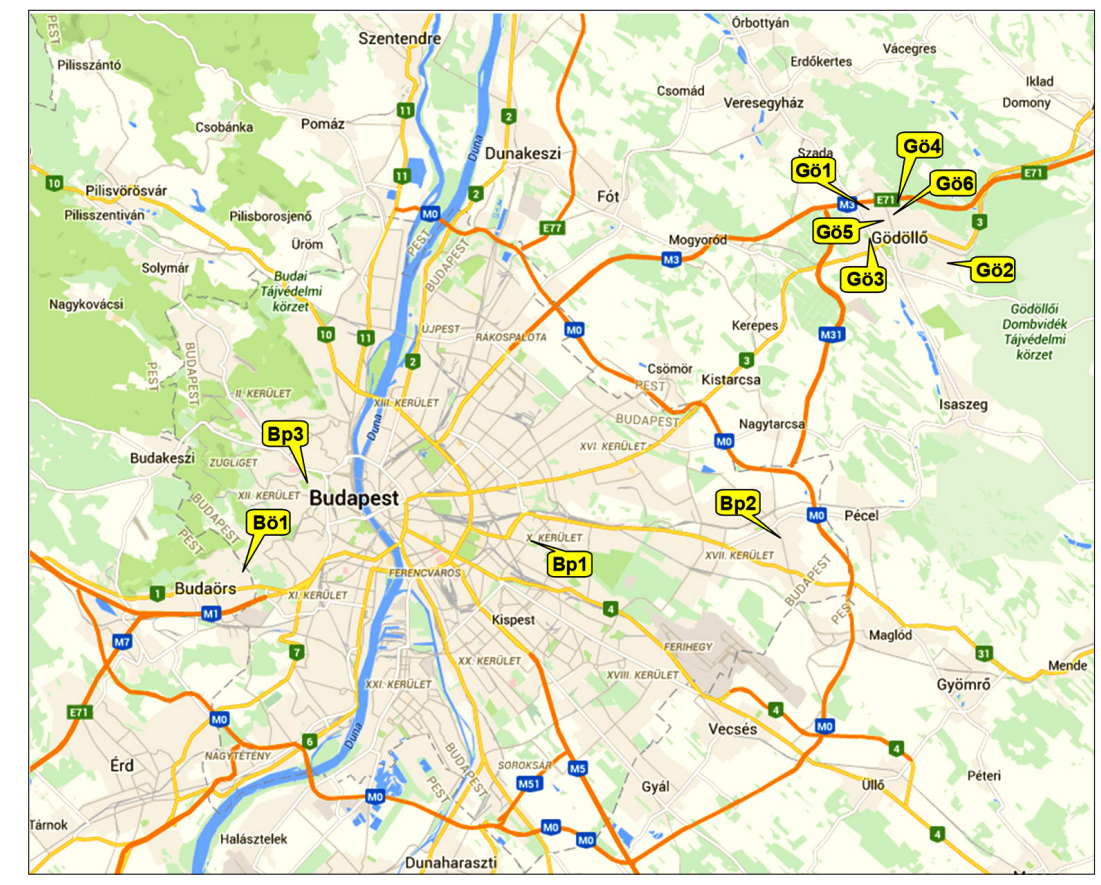

Figure 1. The locations of the homes in Pest county and Budapest

Table 1. Architectural properties of sampled houses

\begin{tabular}{|c|l|c|c|c|c|l|c|}
\hline House & Location & $\begin{array}{c}\text { Size of } \\
\text { House } \\
{\left[\mathrm{m}^{2}\right]}\end{array}$ & $\begin{array}{c}\text { Size of Living } \\
\text { room } \\
{\left[\mathrm{m}^{2}\right]}\end{array}$ & $\begin{array}{c}\text { Year of } \\
\text { Constr. }\end{array}$ & $\begin{array}{c}\text { Year of } \\
\text { Upgrade }\end{array}$ & $\begin{array}{c}\text { Window thermal } \\
\text { transmittance } \mathrm{U}_{\mathrm{w}} \\
{\left[\mathrm{W} / \mathrm{m}^{2} \mathrm{~K}\right](\mathrm{Struct})}\end{array}$ \\
\hline Gö1 & Gödöllö & 106 & 33 & 2008 & - & $44 \mathrm{~cm}$ block brick without insolation & 1.0 (plastic) \\
\hline Gö2 & Gödöllő & 140 & 35 & 2015 & - & $\begin{array}{l}38 \mathrm{~cm} \text { burnt brick+10 cm rock wool } \\
\text { insulation }\end{array}$ & 0.8 (pine wood) \\
\hline Gö3 & Gödöllő & 87 & 30 & 1960 & 2008 & $\begin{array}{l}\text { B30 brick+30 cm polystyrene } \\
\text { insulation }\end{array}$ & 0.82 (plastic) \\
\hline Gö4 & Gödöllő & 120 & 40 & 2002 & 1998 & $\begin{array}{l}30 \mathrm{~cm} \text { YTONG }+15 \text { cm graphite } \\
\text { insulation EPS }\end{array}$ & 1.4 (plastic) \\
\hline Gö5 & Gödöllő & 70 & 25 & 1959 & 2010 & $\begin{array}{l}38 \mathrm{~cm} \text { burnt brick }+8 \mathrm{~cm} \text { inside } \\
\text { thermal insulation }\end{array}$ & 0.82 (plastic) \\
\hline Gö6 & Gödöllő & 95 & 25 & 1955 & 1998 & $\begin{array}{l}\text { pise + B30 bricks+ } 5 \mathrm{~cm} \text { graphite } \\
\text { insulation EPS }\end{array}$ & 1.6 (plastic) \\
\hline Bp1 & Budapest & 90 & 25 & 1933 & 2006 & B36 bricks $+5 \mathrm{~cm}$ thermal insulation & 1.1 (plastic) \\
\hline Bp2 & Budapest & 101 & 30 & 2011 & - & B30 bricks, dryvit, $10 \mathrm{~cm}$ graphite ins. & 1.0 (plastic) \\
\hline Bp3 & Budapest & 90 & 28 & 1930 & - & $64 \mathrm{~cm}$ burnt brick, without insolation & 3.2 (wood) \\
\hline Bö1 & Budaörs & 140 & 35 & 2011 & - & $\begin{array}{l}38.5 \mathrm{~cm} \text { YTONG }+24 \mathrm{~cm} \text { Multipor } \\
\text { insulation }\end{array}$ & 0.82 (plastic) \\
\hline
\end{tabular}


these homes, a blower-door test was carried out according to EN 13789:2002, Bö1 was measured at n50 = 0.245 1/h, Gö5 at $\mathrm{n} 50=0.941 / \mathrm{h}$ and it was impossible to create the required standard $50 \mathrm{~Pa}$ over-pressure in home Bp3.

A buildings energy need is predominantly affected by the parameters and type of installed building services equipment. This includes heat generation, hot water supply system, cooling and ventilation modes. Table 2 includes these parameters, as well as the overall annual energy need derived directly from the meters installed and calibrated by the energy providers $\left[\mathrm{kWh} / \mathrm{m}^{2} \mathrm{a}\right]$. The measured specific energy consumption for houses in Hungary is $180 \mathrm{kWh} / \mathrm{m}^{2} \mathrm{a}$, with upgraded/new homes performing slightly better at $140 \mathrm{kWh} / \mathrm{m}^{2} \mathrm{a}$. The rate of demolition of old houses is only marginal in Hungary, as such, new builds have not significantly decreased the measure specific energy consumption on a national average (Fülöp 2011; Fülöp, Varga 2013). Energy usage based on metered actual consumption will not correlate to energy classification, as operational parameters and user preferences are not taken into consideration in the latter. It is however still an important benchmark, as it enables comparison in material, equipment, orientation and various properties.

The actual energy need of tested homes shows Gö6 and $B p 1$ as average based on metered consumption, with Bp3 performing worse than average. New homes Gö1, Gö2 and $\boldsymbol{B p} \mathbf{2}$ along with upgraded Gö3, Gö4 and Gö5 show better than average energy need. The outlier in the sample is $\boldsymbol{B} \ddot{o} \mathbf{1}$, demonstrating the lowest specific energy need. This house was built and certified according to the standards of Passivehous Institute based in Darmstadt. The operational requirement for these homes based on an average model is below $15 \mathrm{kWh} / \mathrm{m}^{2} \mathrm{a}$. Industry practice estimates that user habit is a significant factor, potentially raising these figures by as much as $50 \%$. Certified operational requirements (certification number HET-00477169) for house $\mathbf{G} \ddot{0} \mathbf{1}$ were indicated as $68.7 \mathrm{kWh} / \mathrm{m}^{2}$ a while metered figures show an actual consumption of $90 \mathrm{kWh} / \mathrm{m}^{2} \mathrm{a}$.

Measurements were taken during the summer of 2015, between the $4^{\text {th }}$ and the $30^{\text {th }}$ of August, repeated through winter 2016 between the $13^{\text {th }}$ of January and $23^{\text {rd }}$ of February. All readings taken encompassed a minimum of 24 hours, with some readings lasting multiple days.

Measurements were taken using 2 separate tools, one specifically calibrated to record $\mathrm{CO}_{2}$ concentration with the other measuring radon. The machines were placed side by side, at an average height of $1 \mathrm{~m}$, ensuring a separation of $1 \mathrm{~m}$ from walls. Radon isotope activity was measured using an AlphaGUARD PQ 2000 Pro (Genitron Instruments, Germany, Frankfurt am Main) with a 0.56 liter active volume ionization chamber detector (Nikolopoulos 2014a; Knoll 2010; EN ISO 11665-5:2012; MSZ EN ISO 11665-5:2016).

$\mathrm{CO}_{2}$ measurements were taken and recorded using CDL 210A (Lindab, Germany, Bad Wünnenberg). Both devices recorded temperature, relative humidity and barometric pressure. Readings were recorded at predetermined intervals (10, 30 or 60 minutes), with data downloads performed after equipment retrieval. Certain sampled homes had readings for external pressure and temperature using a 4 channel ALMEMO 2590-4S (Ahlborn, Germany, Holzkirchen) combined with a FHA646-E1C temperature and humidity sensor. All of the readings were imported into Excel to enable data analysis, displayed in table and graphical formats below.

For homes Gö3, Gö5 and Bö1, air quality analysis was performed with differing amounts of and without ventilation. Home Gö1 was measured for multiple days, including a period of no ventilation or occupancy. The majority of measurements were taken under normal operating parameters of the home, with the data showing the actual average air quality in family homes.

Table 2. Operational parameters of sampled homes

\begin{tabular}{|c|c|c|c|c|c|c|c|c|c|c|c|c|c|}
\hline \multirow[b]{2}{*}{ House } & \multirow{2}{*}{ 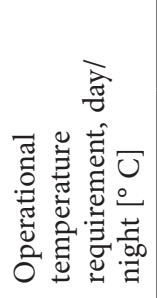 } & \multicolumn{4}{|c|}{ Heating systems } & \multicolumn{3}{|c|}{ Hot Water Supply } & \multirow{2}{*}{ 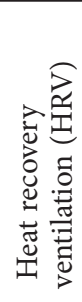 } & \multirow{2}{*}{ 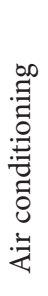 } & \multicolumn{2}{|c|}{$\begin{array}{c}\text { Stove top and } \\
\text { oven }\end{array}$} & \multirow{2}{*}{$\begin{array}{c}\text { Specific heating } \\
\text { energy usage } \\
\text { calculated from } \\
\text { consumption } \\
\text { data } \\
{\left[\mathrm{kWh} / \mathrm{m}^{2} \mathrm{a}\right]}\end{array}$} \\
\hline & & 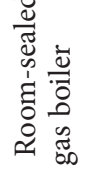 & 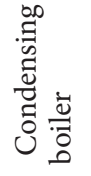 & 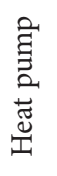 & 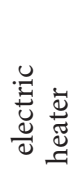 & 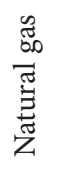 & 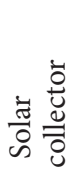 & 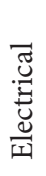 & & & 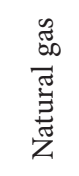 & 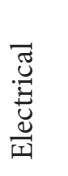 & \\
\hline Gö1 & $22 / 21$ & $x$ & $\checkmark$ & $x$ & $x$ & $\checkmark$ & $x$ & $x$ & $x$ & $x$ & $x$ & $\checkmark$ & 90 \\
\hline Gö2 & $23 / 21$ & $\checkmark$ & $x$ & $x$ & $x$ & $\checkmark$ & $\checkmark$ & $x$ & $x$ & $\checkmark$ & $x$ & $\checkmark$ & 97 \\
\hline Gö3 & $23 / 23$ & $\checkmark$ & $x$ & $x$ & $x$ & $\checkmark$ & $x$ & $x$ & $\checkmark$ & $x$ & $\checkmark$ & $\checkmark$ & 64 \\
\hline Gö4 & $22 / 20$ & $x$ & $\checkmark$ & $x$ & $x$ & $\checkmark$ & $\checkmark$ & $x$ & $\checkmark$ & $x$ & $x$ & $\checkmark$ & 70 \\
\hline Gö5 & $22 / 21$ & $x$ & $x$ & $x$ & $\checkmark$ & $x$ & $x$ & $\checkmark$ & $\checkmark$ & $x$ & $x$ & $\checkmark$ & 32 \\
\hline Gö6 & $23 / 21$ & $x$ & $\checkmark$ & $x$ & $x$ & $\checkmark$ & $x$ & $x$ & $x$ & $x$ & $\checkmark$ & $x$ & 179 \\
\hline Bp1 & $22 / 18$ & $\checkmark$ & $x$ & $x$ & $x$ & $\checkmark$ & $x$ & $x$ & $x$ & $x$ & $x$ & $\checkmark$ & 150 \\
\hline Bp2 & $22 / 21$ & $\checkmark$ & $x$ & $x$ & $x$ & $\checkmark$ & $x$ & $x$ & $x$ & $\checkmark$ & $x$ & $\checkmark$ & 91 \\
\hline Bp3 & $22 / 20$ & $\checkmark$ & $x$ & $x$ & $x$ & $\checkmark$ & $x$ & $x$ & $x$ & $x$ & $\checkmark$ & $x$ & 201 \\
\hline Bö1 & $21 / 21$ & $x$ & $x$ & $\checkmark$ & $x$ & $\checkmark$ & $\checkmark$ & $x$ & $\checkmark$ & $x$ & $x$ & $\checkmark$ & 14 \\
\hline
\end{tabular}




\section{Results and discussion}

To enable comparison between seasonal operations of homes, 8 out of the 10 homes had both summer and winter radon concentration readings done. These were done for a minimum period of 24 hours, with some going on for multiple days. Figure 2 demonstrates the indoor radon concentration of homes both for summer and winter, including averages, standard deviations (SD) and minimum and maximum figures indicated.

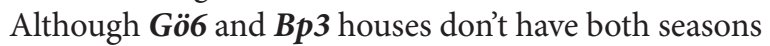
charted due to unavailability of locations, Figure 2. significantly proves that based on the 8 homes that have parallel readings for summer and winter, the latter shows higher concentrations of radon. Winter measurements show a greater spread in both standard deviation and minimummaximum values. One explanation is that manual ventilation during winter is less frequent and done for shorter periods of time. Houses Gö4, Gö5 and Bö1 show lower than average winter radon concentrations of $45 \mathrm{~Bq} / \mathrm{m}^{3}$, attributed to the utilized technology of construction and heat recovery ventilation systems installed. House Gö3 uses similar heat recovery ventilation technology, however the higher average radon concentration could be attributed to the pre-1960 ground insulation technology.

Winter radon concentration values exceeding $200 \mathrm{~Bq} / \mathrm{m}^{3}$ were measured house Gö6 (built in 1955) and Bp1 (built in 1933). Although both houses have undergone modernization and upgrades, ground insulation was not modified. One of the principal causes of radon pollution in houses is naturally occurring radon seepage from the ground (EN ISO 11665-1:2012; MSZ EN ISO 116651:2016).

Houses $\mathbf{G o ̈ 1}, \mathbf{G} \ddot{\mathbf{o}} \mathbf{2}$ and $\boldsymbol{B} \boldsymbol{p} \mathbf{2}$ have better than average energy requirements. Heat recovery ventilation technology has not been included in any of the buildings. This lower energy need is the direct result of better quality doors and windows, $44 \mathrm{~cm}$ walls and condensation boilers for house Gö1, quality insulation and solar supported hot water generation for house $\mathbf{G o ̈ 2}$ and extra insulation for building $\boldsymbol{B p 2}$. This lower energy need and lower operating costs result in visibly deteriorated indoor air quality during winter periods compared to summer values. Winter radon concentrations quadrupled over summer values for home $\boldsymbol{G o ̈ 1}$ while tripling for homes $\boldsymbol{G} \ddot{2} \mathbf{2}$ and $\boldsymbol{B} \boldsymbol{p} 2$. Houses that utilized ventilation technology (Gö3, Gö4, Gö5 and Bö1) experienced a lower than twofold increase in radon concentrations measured compared to summer values. These results demonstrate that while energy efficiency is achievable with insulation, quality windows and expensive heat generation equipment, air quality can only be maintained using heat recovery ventilation especially during winter months.

Further analysis was done for multiple day readings. Figure 3 shows data from house Gö6 measured during the end of January in 2016. The measured concentrations of radon and $\mathrm{CO}_{2}$ were charted against elapsed time.

The house is occupied and operated by elderly retirees, who frequently spend their days home. The ventilation is manual, routinely done in the morning after waking up. This is clearly visible in the daily increase of $\mathrm{CO}_{2}$ and radon levels. Figure 3. clearly shows, with further data available for other homes, radon and $\mathrm{CO}_{2}$ levels increase in parallel in the event that the house in continuously occupied during the day. The amount of increase however is not linked, $\mathrm{CO}_{2}$ is affected by the activities of the occupants and radon increases according to geography, insulation and building materials utilized.

Figure 3 charts the measurements of house Gö6 with manual ventilation. To enable comparison with heat recovery ventilation (HRV), readings from a continuous period of 3 days from house Gö3 were charted on Figure 4 . This building has better than average energy needs, including a HRV device rated at a maximum efficiency of $84 \%$ (Paul Climos F200 built by PAUL Wärmerückgewinnung GmbH., Reinsdorf Germany). To enable comparison between operational parameters, the ventilation

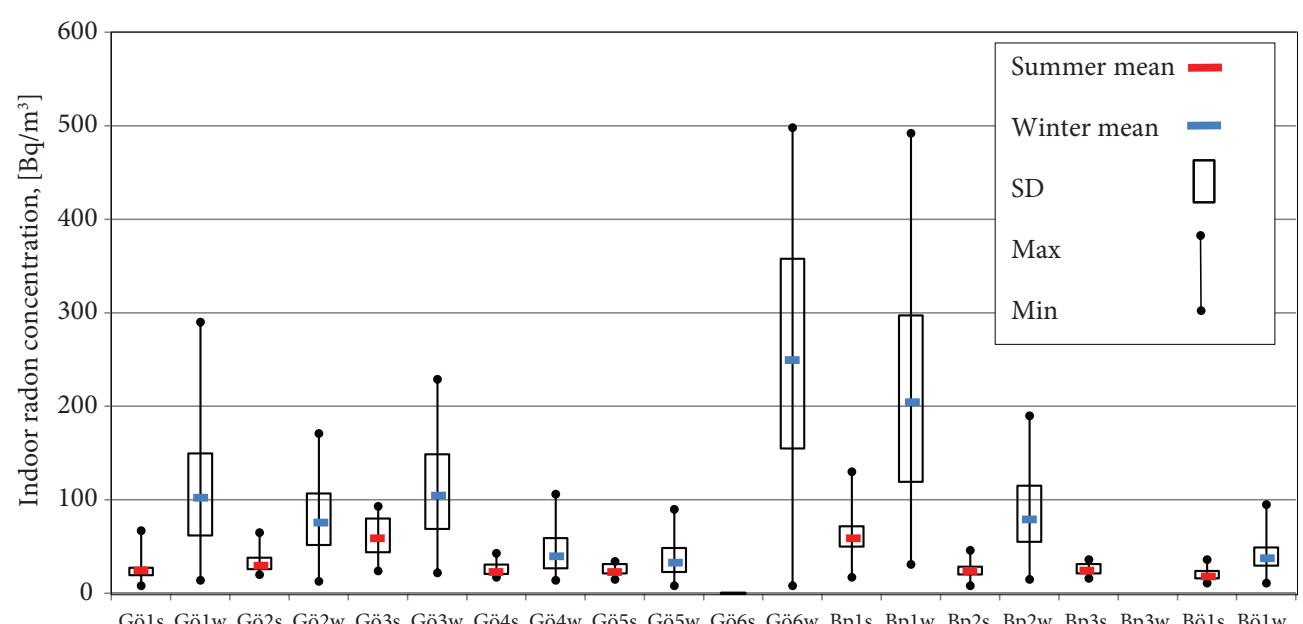

Location and period (summer/winter) of measuremet

Figure 2. Indoor radon concentration for 2015 summer and 2016 winter at the different family houses 
was switched off for day 1 , set to medium for day 2 and increased to maximum airflow for day 3 . All changes were done at 8:00 every day.

Automated ventilation found in heat recovery ventilation technology will affect both radon and $\mathrm{CO}_{2}$ levels. Figure 4 shows that in the event ventilation is switched off, radon will average $122.5 \mathrm{~Bq} / \mathrm{m}^{3}$ with $\mathrm{CO}_{2}$ levels of $1385 \mathrm{ppm}$ in the living room of the home. If ventilation is set to medium, concentrations of both air quality attributes are reduced to an average of $118.7 \mathrm{~Bq} / \mathrm{m}^{3}$ and $1046 \mathrm{ppm}$. Both of these attributes are further reduced to $91.6 \mathrm{~Bq} / \mathrm{m}^{3}$ and $861 \mathrm{ppm}$ on day 3, with automated ventilation set to its maximum parameters. Table 1 shows that house Gö3 was built in 1960, renovated in 2008, explaining the better than average energy efficiency. The house was operated normally during the 3 day measurement period, with the father being away at work during the day, and the mother and the small child spending time in the common areas of the home.

In order to further support the significance of automated ventilation solutions, the device was switched off for the second day of measurement in home Gö5. This home had a comprehensive energy efficiency upgrade in 2010, the upgrades included an F200 Paul Climos unit (PAUL Wärmerückgewinnung GmbH., Reinsdorf Germany). The results are charted on Figure 5 clearly showing that during ventilation on the first day, concentrations of radon never exceeded $34 \mathrm{~Bq} / \mathrm{m}^{3}$, averaged $26.5 \pm 5.2 \mathrm{~Bq} / \mathrm{m}^{3} \mathrm{SD}$. The second day shows a period of no HRV usage, switched off at $8 \mathrm{AM}$, with radon levels rising to $92 \mathrm{~Bq} / \mathrm{m}^{3}$, averaging $54.9 \pm 18.1 \mathrm{~Bq} / \mathrm{m}^{3} \mathrm{SD}$. The stability of the relative humidity and temperate readings is attributed to the insulation of the home. No occupants were present for the measured 2 days in the home, and thus $\mathrm{CO}_{2}$ readings were not taken.

A week-long measurement was taken at house Gö1. There were no occupants for the mid 4 days of the measured period, all doors, windows and shutters were closed. Changes in indoor and outdoor temperature, relative humidity and radon concentration were charted on Figure 6.

The recording of parameters started on the $8^{\text {th }}$ of $\mathrm{Au}$ gust 2015 at 8:00. The family left the home on the $9^{\text {th }}$ at 10:00 as indicated by the first black line break. Up until this moment in time, radon readings are relatively low, attributed to constant manual ventilation through an open porch door enabling natural airflow. It is clearly visible, that radon concentration increase is not constant, rather

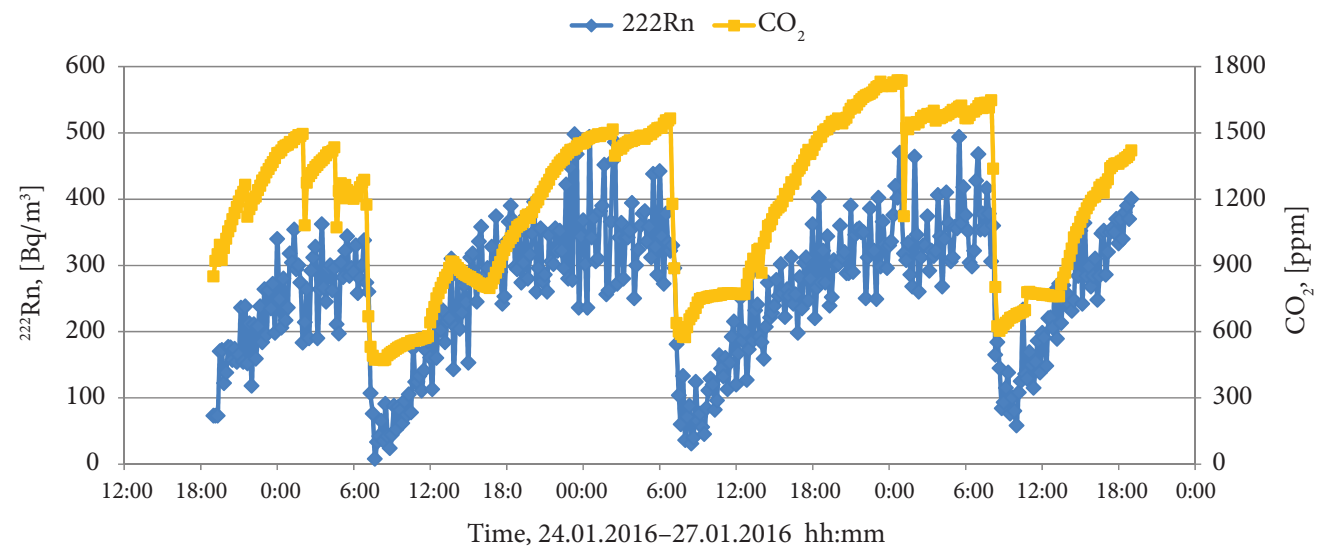

Figure 3. Indoor radon and carbon-dioxide concentration in 2016 winter at Gö6 house

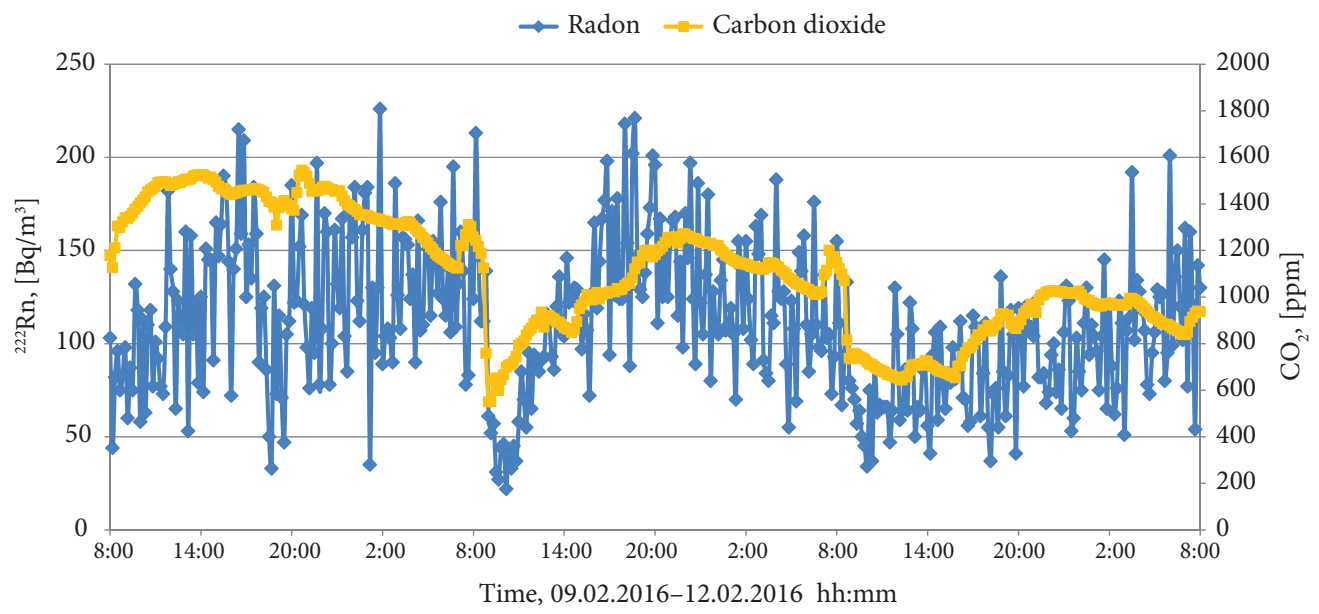

Figure 4. Indoor radon and carbon-dioxide concentration in 2016 winter at Gö3 house in case of 3 day measurement, in addition to various ventilation 
wave-like, following to the day/night cycle. This is likely caused by the difference in indoor and outdoor temperature and the in/exfiltration this difference causes. This pattern conforms to appendix A2 Figure A4 in ISO 116651:2012 showing data on French research of the same subject (Robe et al. 1992).

The architectural properties ( $44 \mathrm{~cm}$ Porotherm brick), quality windows (VEKA, $\mathrm{U}_{\mathrm{w}}=1.0 \mathrm{~W} / \mathrm{m}^{2} \mathrm{~K}$ ) and closed shutters ensured an average inside air temperature of $27^{\circ} \mathrm{C}$ with a relative humidity of $59 \%$. Radon concentration reached a maximum of $234 \mathrm{~Bq} / \mathrm{m}^{3}$ with the 4 and a half day measurement period averaging $150.7 \pm 49.8 \mathrm{~Bq} / \mathrm{m}^{3} \mathrm{SD}$. Figure 6 clearly shows the family returning on the $13^{\text {th }}$ at 17:00 and thoroughly ventilating the home. The measurement period ended on the $15^{\text {th }}$ of August at 8:00. Analysis of the data clearly shows that with constant naturally ventilation through doors/windows, temperature and relative humidity follow the same properties of the outside air mass and radon concentrations averaging $18.3 \pm 5.7 \mathrm{~Bq} / \mathrm{m}^{3} \mathrm{SD}$.
The measurements conducted focused on the changes in radon and $\mathrm{CO}_{2}$ concentration, demonstrating the advantages of technology utilized during construction or upgrade of houses, or during daily operation. The previous examples showed the differences in natural, manual and automatic ventilation, however indoor air quality can be affected by guest arriving demonstrated by Figure 7 or switching on kitchen hoods as evidenced in Figure 8.

Figure 7 charts measurements taken through a 5 day period in the living room of house Gö2, built in 2015 using modern materials and equipment. The parameters charted are radon and $\mathrm{CO}_{2}$ concentration, starting on the Friday, $29^{\text {th }}$ of January 2016 at 8:00. The occupants, a young couple's lifestyle was evident from the recorded values. The occupants leave early and return late during the weekdays. Weekends show increased home based activity, with $\mathrm{CO}_{2}$ levels twice exceeding $1000 \mathrm{ppm}$. The red highlighted area on the diagram shows guests arriving for Sunday night dinner, adversely affecting $\mathrm{CO}_{2}$ and radon

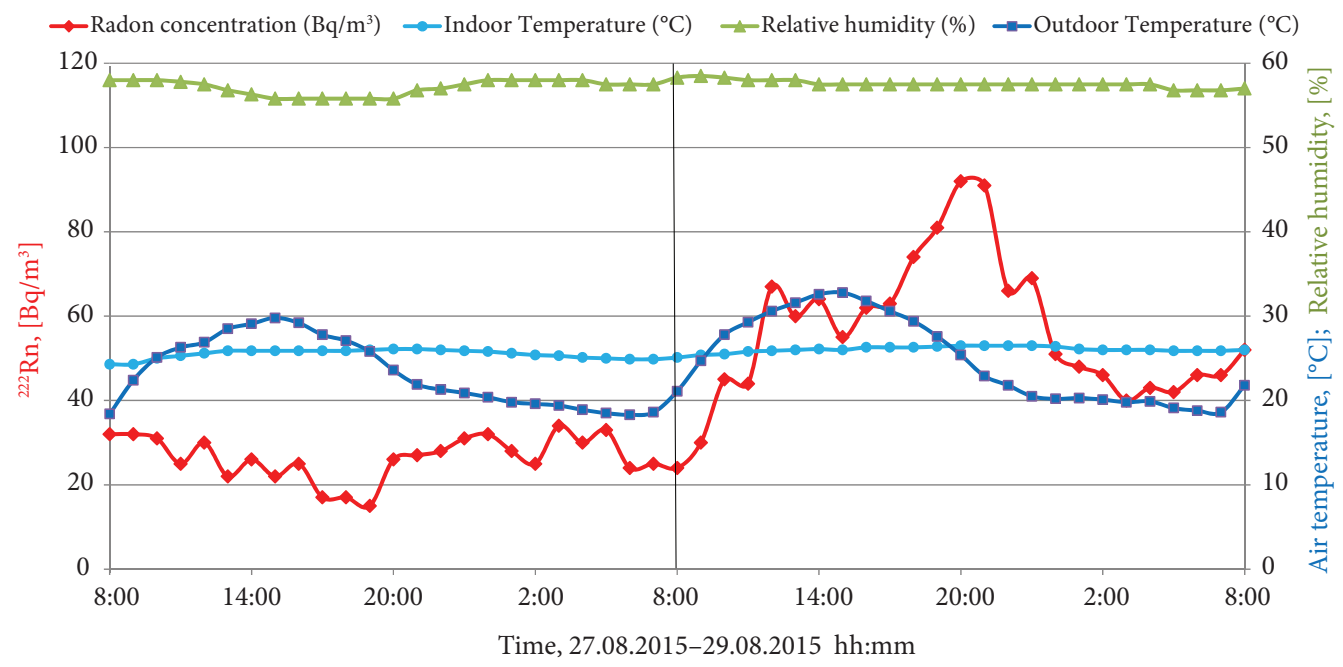

Figure 5. Indoor radon concentration in 2015 summer at $\mathbf{G o ̈ 5}$ house in case of 2 day measurement, with and without ventilation

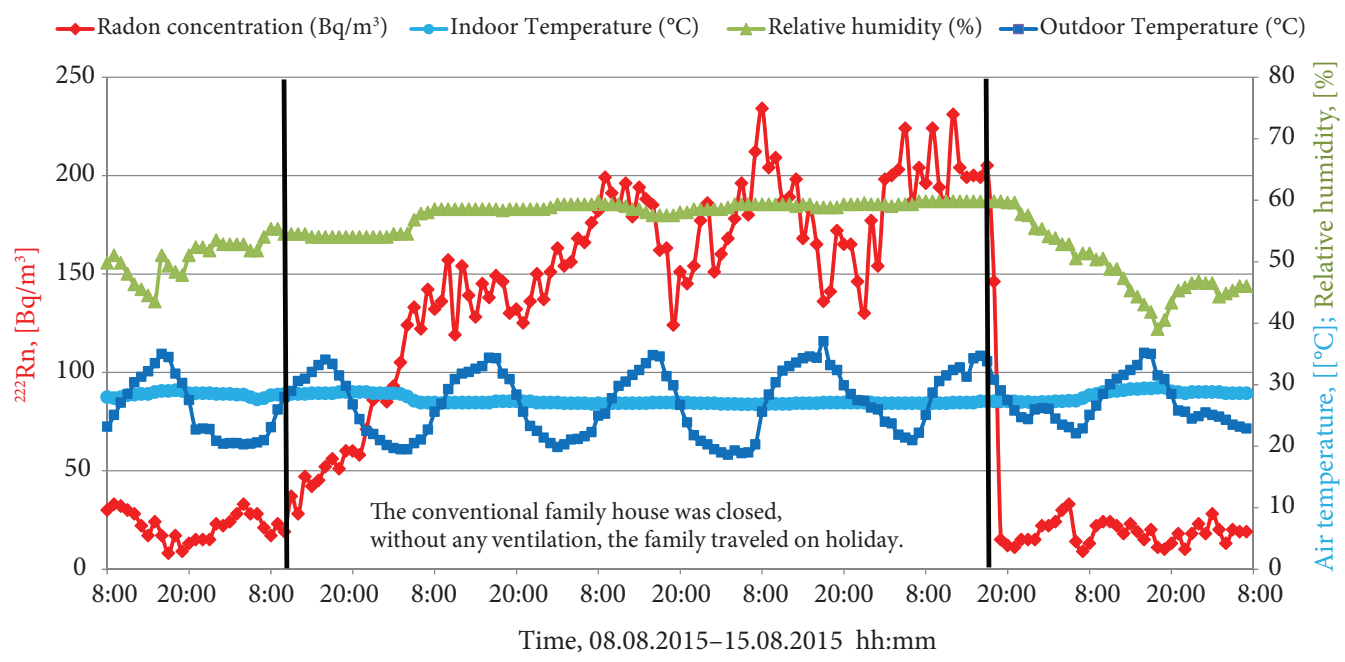

Figure 6. Indoor radon concentration in 2015 summer at Gö1 house 
concentrations. Radon readings drop from an average of $80 \mathrm{~Bq} / \mathrm{m}^{3}$ to under $20 \mathrm{~Bq} / \mathrm{m}^{3}$ due to the multiple openings of the door to let the guests in, which is followed by a sharp increase in $\mathrm{CO}_{2}$ levels reaching $1115 \mathrm{ppm}$, no doubt attributed to the multiple guests and the insufficient ventilation.

Figure 8 charts house Gö1 during a 5 day period starting at 18:00 on the $13^{\text {th }}$ of January 2016. Our previous readings confirmed average radon concentrations of $100 \mathrm{~Bq} / \mathrm{m}^{3}$ for this family home located in Gödöllö. The house is above average in terms of energy efficiency, however no HRV device was installed during or since construction. The family manually ventilates their home twice a day during the winter, these morning and evening window openings are clearly visible in the periodic fluctuations in $\mathrm{CO}_{2}$ levels. The peculiarity of Figure 8 lies in the significant drop in $\mathrm{CO}_{2}$ and radon concentrations at around 9:00 on the $16^{\text {th }}$ of January 2016. The cause was found to be the operation of the kitchen hood during Saturday cooking, this effectively increased the efficiency of the manual ventilation and later the amount natural infiltration. This action significantly and favorably affected indoor air quality of the home.

\section{Conclusions}

Research showing the relationship between indoor air quality and building energy for family houses has not been published yet. There we can state that the study would benefit from increased number of analysed buildings, however the sample size was enough to outline air quality problems of family houses. The concentration of radon in living areas of energy efficient family homes was significantly high, if there was no automated heat recovery ventilation (HRV) unit installed. Our measurements showed radon concentrations at a peak value of $500 \mathrm{~Bq} /$ $\mathrm{m}^{3}$, in comparison to the working HRV measurements of $110 \mathrm{~Bq} / \mathrm{m}^{3}$. Measurements taken during the winter showed a significant increase, HRV equipped homes on averaging twice the summer values (Gö3, Gö4, Gö5 and Bö1), in comparison to homes without HRV, which averaged more than three times the summer values (Gö1, Gö2, Bp1 and Bp2).

Our readings and analysis has highlighted that the $\mathrm{CO}_{2}$ levels can significantly exceed the Pettenkofer-number $(1000 \mathrm{ppm})$, a benchmark of indoor air quality. $\mathrm{CO}_{2}$ concentration is mostly affected by the inhabitants and the

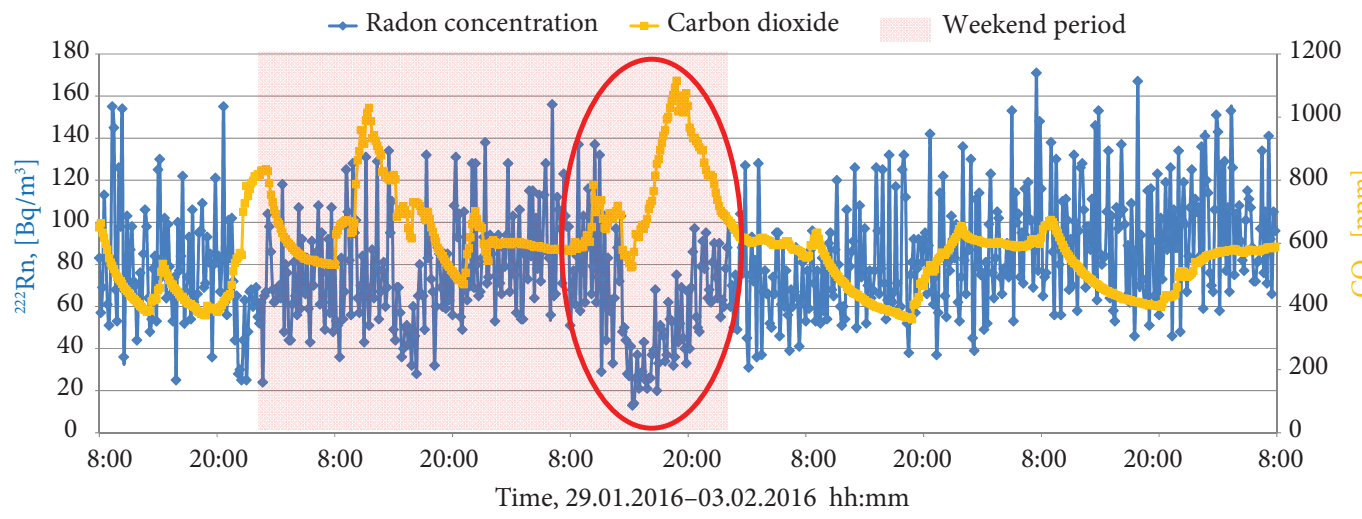

Figure 7. Indoor radon and carbon-dioxide concentration in 2016 winter at $\mathbf{G} \ddot{2} \mathbf{2}$ house in case of 5 day measurement

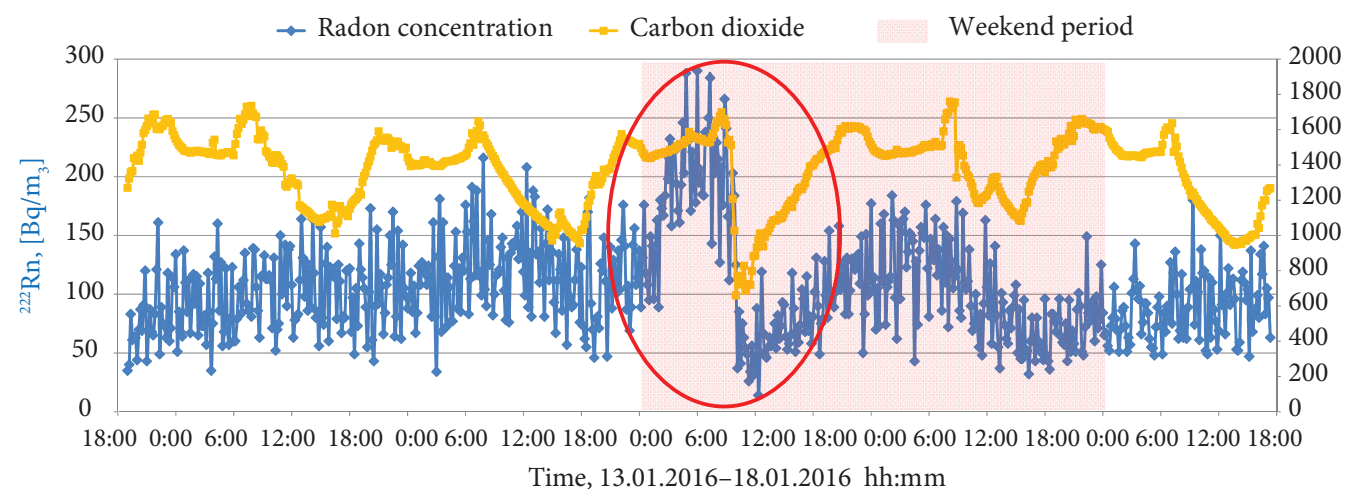

Figure 8. Indoor radon and carbon-dioxide concentration in 2016 winter at $\mathbf{G o ̈ 1}$ house in case of 5 day measurement 
structure and materials used, and are mainly controlled through ventilation. Automated HRV far outperforms manual ventilation in terms of energy efficiency, most prominently during temperature extremes.

Our analysis of measurements taken have shown the direct relationship between the building energy and indoor air quality, highlighting the effects. This analysis shows that the installation of an automated HRV unit will significantly reduce the concentrations of radon and $\mathrm{CO}_{2}$ and increase the energy efficiency of the building. Improving energy efficiency is not only an economic interest but also a means of the environmental protection to reduce the use of harmful emissions and the use of fossil fuels.

\section{References}

Abumurad, K. M. 2001. Chances of lung cancer due to radon exposure in Al-Mazar Al-Shamali, Jordan, Radiation Measurements 34(1-6): 537-540. https://doi.org/10.1016/S1350-4487(01)00223-2

Bánhidi, L.; Kajtár, L. 2000. Komfortelmélet (Comfort Theory). Müegyetemi Kiadó, Budapest (in Hunhgarian)

Baumann, M. (Ed.) 2009. Épületenergetika (Building Energy). Guide book. PTE Pollack Mihály Műszaki Kar, Pécs (in Hungarian).

Becker, K. 2003. Health effects of high radon environments in Central Europe: Another Test for the LNT Hypothesis?, Nonlinearity in Biology, Toxicology, and Medicine 1(1): 3-35. https://doi.org/10.1080/15401420390844447

Benécs, J.; Barótfi, I. 2015. Ablakok energetikai felújítása egyszerüen (Windows simply energy refurbishment), Magyar Épületgépészet 64(5): 21-24 (in Hungarian).

Butkus, D.; Morkünas, G.; Pilkyte, L. 2005. Ionizing radiation in buildings: Situation and dealing with problems, Journal of Environmental Engineering and Landscape Management 13(2): 103-107.

Dagiliūtè, R.; Juozapaitienė, G. 2015. Socio-economic assessment in environmental impact assessment: experience and challenges in Lithuania, Journal of Environmental Engineering and Landscape Management 23(3): 211-220. https://doi.org/10.3846/16486897.2015.1002842

Darby, S.; Hill, D.; Auvinen, A.; Barrios-Dios, J. M.; Baysson, H.; Bochicchio, F.; Deo, H.; Falk, R.; Forastiere, F.; Hakama, M.; Heid, I.; Kreienbrock, L.; Kreuzer, M.; Lagarde, F.; Makelainen, I.; Muirgead, C.; Oberaigner, W.; Pershagen, G.; RuaniRavina, A.; Ruosteenoja, E.; Rosario, A. S.; Tirmarche, M.; Tomasek, L.; Whitley, E.; Wichmann, H. E.; Doll, R. 2004. Radon in homes and risk of lung cancer: collaborative analysis of individual data from 13 European case-control studies, British Medical Journal 330: 223-226.

https://doi.org/10.1136/bmj.38308.477650.63

Decree of Government 176/2008. (VI.30.). Az épületek energetikai jellemzőinek tanúsításáról [The certification of energy characteristics of buildings] (in Hungarian).

Decree of Government 261/2015. (IX. 14.). Amendening Decree of Government 176/2008. (VI.30.).

Decree of Government 487/2015. (XII. 30.). Az ionizáló sugárzás elleni védelemröl és a kapcsolódó engedélyezési, jelentési és ellenőrzési rendszerről [Protection against ionizing radiation and related licensing, reporting and verification system] (in Hungarian).
Decree of TNM 7/2006.(V.24.). Az épületek energetikai jellemzőinek meghatározásáról [The determination of energy characteristics of buildings] (in Hungarian).

Directive 2002/91/EC on energy performance of buildings.

Directive 2010/31/EU on energy efficiency of buildings.

Directive 2012/27/EU on energy efficiency, amending Directives 2009/125/EC and 2010/30/EU and repealing Directives 2004/8/EC and 2006/32/EC.

Ebel, W.; Großklos, M.; Knissel, J.; Loga, T.; Müller, K. 2003. Wohnen in Passiv-und Niedrigenergiehäusern. Institut Wohnen und Umwelt, Darmstadt.

EN 13789:2002. Thermal Performance of buildings - Determination of air permeability of buildings - Fan pressurization method.

EN ISO 11665-1:2012. Measurement of radioactivity in the environment. Air: radon-222. Part 1: Origins of radon and its short-lived decay products and associated measurement methods.

EN ISO 11665-5:2012. Measurement of radioactivity in the environment. Air: radon-222. Part 5: Continuous measurement metho of the activity concentration.

Feist, W.; Schnieders, J.; Dorer, V.; Haas, A. 2005. Re-inventing air heating: Convenient and comfortable within the frame of the Passive House concept, Energy and Buildings 37(11): 1186-1203. https://doi.org/10.1016/j.enbuild.2005.06.020

Frontczak, M.; Wargocki, P. 2011. Literature survey on how different factors influence human comfort in indoor environments, Building and Environment 46(4): 922-937. https://doi.org/10.1016/j.buildenv.2010.10.021

Fülöp, O. 2011. NEGAJOULE 2020. A Magyar épületekben rejlő energiamegtakarítási lehetöségek [NEGAJOUL 2020. Energy saving opportunities in Hungarian building]. Report of Energiaklub.

Fülöp, O.; Varga, K. 2013. Lakóépületben elérhetö megújulóenergia-potenciál [Available renewable energy potential], Study of Energiaklub.

Géczi, G.; Béres, A. 2011. Levegőtisztaság-védelem [Air Purity Protection]. Lecture Notes. Szent István Egyetem, Gödöllő (in Hungaria).

Goyal, R.; Khare, M.; Kumar, P. 2012. Indoor air quality: current status, missing links and future road map for India, Journal of Civil Environmental Engineering 2: 118.

https://doi.org/10.4172/2165-784X.1000118

Hámori, K.; Tóth, E.; Losonci, A.; Minda, M. 2006b. Some remarks on the indoor radon distribution in a country, Applied Radiation and Isotopes 64(8): 859-863.

https://doi.org/10.1016/j.apradiso.2006.02.098

Hámori, K.; Tóth, E.; Pál, L.; Köteles, G.; Losonci, A.; Minda, M. 2006a. Evaluation of indoor radon measurements in Hungary, Journal of Environmental Radioactivity 88: 189-198. https://doi.org/10.1016/j.jenvrad.2006.02.002

Hungarian Standards MSZ EN ISO 11665-1:2016 Magyar Szabvány. A környezeti radioaktivitás mérése. Levegö: radon-222, 5. rész Az aktivitáskoncentráció meghatározása folyamatos mérési módszerrel.

Hungarian Standards MSZ EN ISO 11665-1:2016. A környezeti radioaktivitás mérése. Levegő: radon-222, 1. rész: A radon és a rövid felezési idejü bomlástermékek eredete és az ehhez kapcsolódó mérési módszerek.

Hussein, Z. A.; Jaafar, M. S.; Ismail, A. H. 2013. Measurements of Indoor Radon-222 Concentration inside Iraqi Kurdistan: case study in the summer season, Journal of Nuclear Medicine \& Radiation Theraphy 4: 143.

https://doi.org/10.4172/2155-9619.1000143 
ICRP 1991. 1990 Recommendations of the international commission on radiological protection, ICRP Publication 60. Ann. ICRP 21(1-3).

ICRP 1993. Protection Against Radon-222 at Home and at Work. ICRP Publication 65. Ann. ICRP 23(2).

Kačerauskas, T. 2016. Environmental discourses and the question of creative environment in a city, Journal of Environmental Engineering and Landscape Management 24(2): 108-115. https://doi.org/10.3846/16486897.2016.1141097

Kajtár, L.; Szekeres, J. 2011. Tantermek szellőztetése, frisslevegőellátása [Classrooms ventilation, fresh air supply, Magyar Installateur 2-3: 64-67 (in Hungarian).

Kalmár, F. 2016. Személyi szellőző berendezés fejlesztése a Debreceni Egyetem Épületgépészeti és Létesítménymérnöki Tanszékén [Developing individual ventillator on Department Building Engineering in Debrecen University], Magyar Épületgépészet 65(4): 3-7 (in Hungarian).

Katona, T.; Kanyár, B.; Somlai, J.; Molnár, Á. 2007. Determining ${ }^{222} \mathrm{Rn}$ daughter activities by simultaneous alpha- and beta-counting and modeling, Journal of Radioanalytical and Nuclear Chemistry 272(1): 69-74.

https://doi.org/10.1007/s10967-006-6793-4

Knoll, G. F. 2010. Radiation Detection and Measurement. $4^{\text {th }}$ ed. John Wiley \& Sons, Inc.

Köteles, Gy. J. 2007. Radon risk in spas? Central European Journal of Occupational and Environmental Medicine 13(1): 3-16.

Lázár, I.; Tóth, E.; Köteles, Gy. J.; Puhó, E.; Czeizel, A. E. 2005. An inverse association between cancer mortality rate of women and residential radon in 34 Hungarian villages, Journal of Radioanalytical and Nuclear Chemistry 266(1): 43-48. https://doi.org/10.1007/s10967-005-0866-7

Liu, D.; Zhao, F. Y.; Tang G.-F. 2010. Active low-grade energy recovery potential for building energy conservation, Renewable \& Sustainable Energy Reviews 14: 2736-2747.

Magyar, Z.; Németh, G.; 2015. Közel nulla energiaigényü középületek követelményrendszere dél- és kelet-európai országokban [Nearly zero energy public buildings' requirement system in southern and eastern European countries], Magyar Épületgépészet 64(1-2): 3-7 (in Hungarian).

Minda, M.; Tóth, Gy.; Horváth, I.; Barnet, I.; Hámori, K.; Tóth, E. 2009. Indoor radon mapping and its relation to geology in Hungary, Environmental Geology 57(3): 601-609.

https://doi.org/10.1007/s00254-008-1329-6

Müllerová, M.; Kozak, K.; Kovács, T.; Smetanová, I.; Csordás, A.; Gradziel, D.; Holy, K.; Mazur, J.; Moravcsik, A.; Neznal, M.; Neznal, M. 2016. Indoor radon survey in Visegrad countries, Applied Radiation and Isotopes 110: 124-128. https://doi.org/10.1016/j.apradiso.2016.01.010

Nikl, I. 1996. The radon concentration and absorbed dose rate in Hungarian dwellings, Radiation Protection Dosimetry 67(3): 225-228.

https://doi.org/10.1093/oxfordjournals.rpd.a031821

Nikolopoulos, D.; Kottou, S.; Louizi, A.; Petraki, E.; Vogiannis, E.; Yannakopoulos, P. H. 2014b. Factors affecting indoor radon concentrations of Greek dwellings through multivariate statistics, Journal Physical Chemistry \& Biophysics 4: 145. https://doi.org/10.4172/2161-0398.1000145

Nikolopoulos, D.; Petraki, E.; Temenos, N.; Kottou, S.; Koulougliotis, D.; Yannakopoulos, P. H. 2014a. Hurst exponent analysis of indoor radon profiles of Greek apartment dwellings, Journal of Physical Chemistry \& Biophysics 4: 168. https://doi.org/10.4172/2161-0398.1000168

Robe, M. C.; Rannou, A.; Bronec, J. L. 1992. Radon Measurement in the Environment in France, Radiation Protection
Dosimetry 45(1-4): 455-457.

https://doi.org/10.1093/oxfordjournals.rpd.a081580

Schnieders, J. 2009. Passive houses in South West Europe. A quantitative investigation of some passive and active space conditioning techniques for highly energy efficient dwellings in the South West European region. $2^{\text {nd }}$ corrected ed. Passivhaus Institut, Darmstadt.

Somlai, J.; Gorjánácz, Z.; Várhegyi, A.; Kovács, T. 2006. Radon concentration in houses over a closed Hungarian uranium mine, Science of the Total Environment 367(2-3): 653-665. https://doi.org/10.1016/j.scitotenv.2006.02.043

Szabó, K. Zs.; Horváth, Á.; Szabó, Cs. 2014a. Geogén radonpotenciál térképezés Pest és Nógrád megye területén [Geogenically radonpotenciál mapping Pest and Nógrád county], Nukleon 7(153): 9 (in Hungarian).

Szabó, K. Zs.; Jordan, Gy.; Horváth, Á.; Szabó, Cs. 2014b. Mapping the geogenic radon potential: methodology and spatial analysis for Central Hungary, Journal of Environmental $\mathrm{Ra}$ dioactivity 129: 107-120.

https://doi.org/10.1016/j.jenvrad.2013.12.009

Szabó, K. Zs.; Jordan, Gy.; Szabó, Cs.; Horváth, Á.; Holm, Ó.; Kocsy, G.; Csige, I.; Szabó, P.; Homoki, Zs. 2014c. Radon and thoron levels, their spatial and seasonal variations in adobe dwellings - a case study at the great Hungarian plain, Isotopes in Environmental and Health Studies 50(2): 211-225. https://doi.org/10.1080/10256016.2014.862533

Szállási, Á. 2001. Pettenkofer, a közegészségtan (nem tévedhetetlen) pápája [Pettenkofer, the (not unerring) pope of public health], Orvosi Hetilap 142(48): 2687-2690 (in Hungarian).

Szerbin, P.; Köteles, Gy.; Stúr, D. 1994. Radon concentrations in Rudas thermal bath, Budapest, Radiation Protection Dosimetry 56(1-4): 319-321. https://doi.org/10.1093/oxfordjournals.rpd.a082479

Tóth, E. 1992. Radon a magyar falvakban [Radon in the Hungarian villages], Fizikai Szemle 2: 44-49 (in Hungarian).

Tóth, E.; Hámori, K. 2005. A lakótéri radonszint eloszlásról [Distribution of indoor radon levels], Fizikai Szemle 11: 375-378 (in Hungarian).

Tóth, E.; Lázár, I.; Selmeczi, D.; Marx, G. 1998. Lower cancer risk in medium high radon, Pathology and Oncology Research 4(2): $125-129$.

https://doi.org/10.1007/BF02904706

UNSCEAR 2000. Sources and effects of ionizing radiation. United Nations Scientific Committee on the Effects of Atomic Radiation 2000 Report to the General Assembly.

Vasilyev, A.; Yarmoshenko, I. 2016. Effect of energy-efficient measures in building construction on indoor radon in Russia, Radiation Protection Dosimetry. https://doi.org/10.1093/rpd/ncw149

Wang, Y.; Zhao, F. Y.; Kuckelkorn, J.; Liu, D.; Liu, L.-Q.; Pan, X.-C. 2014b. Cooling energy efficiency and classroom air environment of a school building operated by the heat recovery air conditioning unit, Energy 64: 991-1001.

Wang, Y.; Zhao, F. Y.; Kuckelkorn, J.; Spliethoff, H.; Rank, E. 2014a. School building energy performance and classroom air environment implemented with the heat recovery heat pump and displacement ventilation system, Applied Energy 114: 58-68.

Xu, J.; Zhang, M.; Shao, L.; Kang, J. 2016. Subjective evaluation of the environmental quality in China's industrial corridors, Journal of Environmental Engineering and Landscape Management 24(1): 21-36.

Zeeb, H.; Shannoun, F. 2009. WHO handbook on indoor radon: $a$ public health perspective. World Health Organization. 